\title{
Współczesne problemy kodyfikacji prawa postępowania cywilnego
}

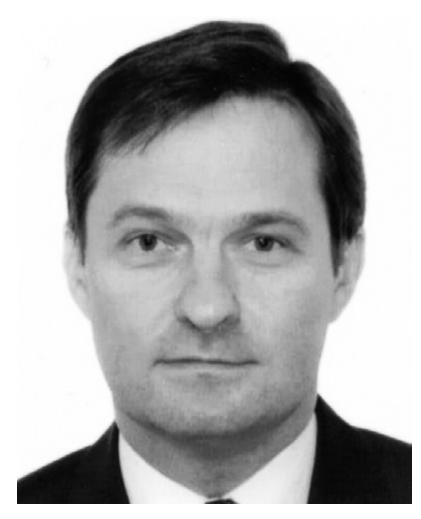

\section{Karol Weitz}

Kierownik Katedry Postępowania Cywilnego na Wydziale Prawa i Administracji Uniwersytetu Warszawskiego, sędzia Sądu Najwyższego orzekajacy w Izbie Cywilnej (od grudnia 2014 r.), autor ponad 200 publikacji naukowych z zakresu prawa postępowania cywilnego, członek International Association of Procedural Law (IAPL), redaktor naczelny kwartalnika Polski Proces Cywilny, w latach 20112015 członek Komisji Kodyfikacyjnej Prawa Cywilnego działającej przy Ministrze Sprawiedliwości, w latach 2010-2014 członek Rady Legislacyjnej przy Prezesie Rady Ministrów.

$\triangle$ k.weitz@wpia.uw.edu.pl

https://orcid.org/0000-0003-0408-5374

\section{Contemporary Problems of the Codification of Civil Procedural Law}

\begin{abstract}
The author considers the issue of whether the postulate of creating a new code of civil procedure is still valid. He comes to the conclusion that the following arguments support the new codification: the poor state of the current Code of Civil Procedure and the need to take into account the challenges facing civil procedural law like constitutionalization, Europeanization and digitalization of this law, as well as the creation of new solutions to protect collective interests. However, he indicates, as obstacles to the preparation of the new code, the collapse of the culture of creating law in Poland, problems resulting from changes in the justice system and threats resulting from legal populism.
\end{abstract}

Słowa kluczowe: nowa kodyfikacja, konstytucjonalizacja, europeizacja, informatyzacja, legislacja

Key words: new codification, constitutionalization, Europeanization, digitalization, legislation

https://doi.org/10.32082/fp.v0i3(59).357

1. Przemiany społeczno-polityczne w 1989 r. zapoczątkowały w naszym kraju proces przebudowy polskiego porządku prawnego w każdej dziedzinie. Zasadniczym kierunkiem tego procesu było odejście od systemu prawnego państwa „realnego socjalizmu”, wzorowanego na modelu sowieckim i właściwego tzw. państwom „demokracji ludowej”, i stworzenie na jego miejsce systemu prawnego charakterystycznego dla demokra- cji liberalnej, opartej na zasadzie demokratycznego państwa prawnego. Do dziedzin prawa, które wymagały przeprowadzenia gruntownych reform, należało także prawo postępowania cywilnego ${ }^{1}$.

1 W dalszych uwagach pojęcia „prawo postępowania cywilnego" $i$,prawo procesowe cywilne" będą używane zamiennie, z pełną świadomością występujących w tym zakresie kontrowersji terminologicznych. 
W chwili politycznego przełomu obowiązywał w Polsce Kodeks postępowania cywilnego z 1964 r. $^{2}$ w kształcie, który od chwili jego uchwalenia nie był przedmiotem poważniejszych zmian ${ }^{3}$. Ugruntowywał on „osiągnięcia" reform prawa procesowego cywilnego dokonanych w okresie powojennym, które stanowiły przykład przymusowej implementacji rozwiązań charakterystycznych dla procesu socjalistycznego ${ }^{4}$. $Z$ oczywistych względów nie mógł w takim kształcie funkcjonować w nowej rzeczywistości społeczno-politycznej, w kraju o gospodarce rynkowej, kształtującym w inny sposób relacje pomiędzy obywatelem a państwem, w duchu indywidualizmu i autonomii jednostek, przy zachowaniu - w niezbędnym jedynie zakresie - pomocniczej roli czynnika publicznego.

Przebudowa prawa postępowania cywilnego od początku realizowana była w drodze kolejnych nowelizacji dotychczasowego kodeksu ${ }^{5}$. Nie zdecydowano się na przygotowanie i wprowadzenie w życie w krót-

2 Ustawa z dnia 17.11.1964 r. - Kodeks postępowania cywilnego. Pierwotny tekst kodeksu został opublikowany w Dz.U. nr 43, poz. 296.

3 Najobszerniejsze zmiany przed $1989 \mathrm{r}$. wprowadzone zostały na mocy ustawy z dnia 18.04.1985 r. o zmianie ustawy Kodeks postępowania cywilnego, Dz.U. nr 20, poz. 86. Dotyczyły one m.in. modelu rozstrzygania spraw z zakresu prawa pracy i ubezpieczeń społecznych.

4 Informacyjnie w tej kwestii por. K. Weitz, Czy nowa kodyfikacja postępowania cywilnego?, „Państwo i Prawo” 2007, nr 3, s. 14-15 i powołaną tam dalszą literaturę. Szerzej, z uwzględnieniem kontekstu społeczno-politycznego, względów ideologicznych i zmian ustrojowych w wymiarze sprawiedliwości w powojennej Polsce zob. A. Machnikowska, 50-lecie Kodeksu postępowania cywilnego z dalekiej i bliskiej perspektywy, „Kwartalnik Prawa Prywatnego” 2015, z. 3, s. 551-573. W kwestii przebudowy ideologicznej w zakresie zasad procesu cywilnej zob. J. Gudowski, O kilku naczelnych zasadach procesu cywilnego - wczoraj, dziś, jutro (w:) Prawo prywatne czasu przemian. Księga pamiątkowa dedykowana Profesorowi Stanisławowi Soltysińskiemu, Poznań 2005, s. $1018-1022$.

5 Por. w szczególności T. Ereciński, O nowelizacji kodeksu postępowania cywilnego w ogólności, „Przegląd Sądowy” 1996, nr 10, s. 4 i n.; W. Broniewicz, Nowelizacja prawa postępowania cywilnego $z$ dnia 1 marca 1996 r., „Kwartalnik Prawa Prywatnego" 1997, z. 2, s. 199 i n.; K. Weitz, Die Entwicklung kim czasie całkowicie nowej kodyfikacji. Ta wyjściowa metoda reformowania prawa procesowego cywilnego wkrótce okazała się nie tylko sposobem na wprowadzenie pierwszych i najpilniejszych zmian, lecz stała się w następnych latach także drogą dokonywania kolejnych przekształceń poszczególnych regulacji procesowych w sprawach cywilnych ${ }^{6}$. Służyły one po części modyfikacji wcześniej przeprowadzonych reform, a po części realizacji kolejnych bieżących wyzwań stających coraz szybciej i częściej przed praktyką i nauką postępowania cywilnego.

Dyskusja nad zagadnieniem, czy potrzebny jest nowy Kodeks postępowania cywilnego, nie pojawiła się wprawdzie od razu, jednak nastąpiło to wkrótce po tym, jak - zdawałoby się - zaspokojone zostały najbardziej zasadnicze oczekiwania dotyczące przebudowy unormowań procesowych związane z transformacją ustrojową. W literaturze zwrócono uwagę, że kodeks z 1964 r. nie tylko powstał w innej epoce, ale - po kilku gruntownych nowelizacjach - przestał być aktem spójnym i operatywnym w codziennym praktycznym funkcjonowaniu. Świadomość, że musi być on poddawany kolejnym, mniej lub bardziej rozbudowanym reformom, mającym zmierzać do usprawnienia rozpoznawania spraw cywilnych oraz egzekwowania rozstrzygnięć wydawanych w tych sprawach i odpowiadać jednocześnie nowym wyzwaniom współczesnego obrotu prawnego, skłoniła część środowiska naukowego do postawienia problemu potrzeby opracowania nowej kodyfikacji postępowania cywil-

des polnischen Zivilprozessrechts nach der politischen Wende 1989, „ZZP International” 2006, t. 11, s. 96-115.

$6 \mathrm{Na}$ tamat nowelizacji w kolejnych latach zob. m.in. T. Ereciński, Wprowadzenie do ustawy z dnia 24 maja 2000 r. (w:) Kodeks postępowania cywilnego po nowelizacjach $z 2001 \mathrm{r}$. Warszawa 2002, s. 1 i n.; M. Manowska, Zmiany w kodeksie postępowania cywilnego wprowadzone w 2004 r., „Przegląd Sądowy” 2005, nr 5, s. 3 i n.; J. Jankowski, Nowelizacje KPC wprowadzone w 2005 r., Warszawa 2005, passim. Por. także zbiór rozpraw H. Dolecki, K. Flaga-Gieruszyńska (red.), Ewolucja polskiego postępowania cywilnego wobec przemian politycznych, społecznych i gospodarczych. Materialy konferencyjne Ogólnopolskiego Zjazdu Katedr Postępowania Cywilnego Szczecin-Niechorze 28-30.9.2007 r., Warszawa 2009, passim. 
nego ${ }^{7}$. Oznaczało to, że odtąd kontynuacja rozwoju prawa postępowania cywilnego mogła się odbywać dwutorowo. Z jednej strony mogły być dokonywane na bieżąco kolejne cząstkowe nowelizacje obowiązującego kodeksu, a także ustaw okołokodeksowych, z drugiej strony - w dłuższej perspektywie - mógł zostać przygotowany nowy Kodeks postępowania cywilnego, wzorem innych współczesnych kodyfikacji, które pojawiły się w ostatnich latach ${ }^{8}$. Problematyce stanu obowiązującego kodeksu i drogi do zastąpienia go nową kodyfikacją środowisko procesualistów cywilnych poświęciło w krótkim odstępie czasu trzy kolejne Zjazdy Katedr i Zakładów Postępowania Cywilnego $\left(2005^{9}, 2013^{10}\right.$ i $\left.2015^{11}\right)$. Zapoczątkowano w ten sposób stworzenie intelektualnej i teoretycznej podbudowy dla prac nad nowoczesnym Kodeksem postępowania cywilnego, mającym nie tylko zapewniać w większym stopniu efektywność ochrony prawnej udzielanej

7 Pozytywnie w kwestii takiej potrzeby wypowiedzieli się T. Ereciński, O potrzebie nowego kodeksu postępowania cywilnego, „Państwo i Prawo” 2004, nr 4, s. 7-10; F. Zedler, Co dalej z kodeksem postępowania cywilnego (w:) Czterdziestolecie Kodeksu postępowania cywilnego. Zjazd Katedr Postępowania Cywilnego w Zakopanem (7.-9.10.2005 r.), Kraków 2006, s. 309 i n.; K. Weitz, Czy nowa kodyfikacja..., s. 20-23. Przeciwko przygotowaniu nowego Kodeksu postępowania cywilnego opowiedział się natomiast W. Broniewicz, Czy potrzebny jest nowy kodeks postępowania cywilnego?, „Państwo i Prawo" 2004, nr 4, s. 11 i n.

8 Punktem odniesienia stały się w szczególności prace nad przygotowaniem jednolitego szwajcarskiego Kodeksu postępowania cywilnego, por. P. Rylski, Projekt nowej jednolitej szwajcarskiej procedury cywilnej w świetle dyskusji nad założeniami nowego polskiego kodeksu postępowania cywilnego, „Przegląd Sądowy” 2007, nr 11-12, s. 164 i n.

9 Czterdziestolecie Kodeksu postępowania cywilnego. Zjazd Katedr Postępowania Cywilnego w Zakopanem (7.9.10.2005 r.), Kraków 2006.

10 K. Markiewicz, A. Torbus (red.), Postępowanie rozpoznawcze w przyszłym Kodeksie postępowania cywilnego, Warszawa 2014.

11 E. Marszałkowska-Krześ, I. Gil, Ł. Błaszczak (red.), Kodeks postępowania cywilnego z perspektywy pięćdziesięciolecia jego obowiązywania. Doświadczenia i perspektywy, Sopot 2016. w postępowaniu cywilnym, ale odpowiadać również na wyzwania współczesności ${ }^{12}$.

$\mathrm{W}$ praktyce dominującym trendem niezmiennie pozostały kolejne bieżące nowelizacje dotychczasowego Kodeksu postępowania cywilnego. Obejmowały one różne obszary prawa postępowania cywilnego, służyły uwzględnianiu postępujących procesów konstytucjonalizacji, europeizacji i informatyzacji tego prawa i stanowiły - częściową - odpowiedź na wyzwania płynące z rosnącej masowości spraw cywilnych o charakterze typowym i powtarzalnym ${ }^{13}$. W tle pozostawała dyskusja nad dylematem pomiędzy dalszym reformowaniem kodeksu a jego definitywnym zastąpieniem nową kodyfikacją. Stopniowo utrwalało się jednak stanowisko, że dylemat ten należy rozstrzygnąć w kierunku podjęcia trudu opracowania nowego kodeksu ${ }^{14}$. Dyskusje w kwestii możliwych nowych rozwiązań przybierały postać nie tylko szczegółowych doktrynalnych wypowiedzi co do różnych

12 Co do złożoności zagadnienia efektywności ochrony prawnej i jej uwarunkowań, w szczególności ustrojowych i procesowych, zob. T. Ereciński, K. Weitz, Efektywność ochrony prawnej udzielanej przez sądy w Polsce, „Przegląd Sądowy” 2005, nr 10, s. 3 i n.

13 K. Markiewicz (red.), Reforma postępowania cywilnego w świetle projektów Komisji Kodyfikacyjnej, Warszawa 2011, passim; K. Weitz, Reformen des Zivilprozessrechts in der dritten polnischen Republik (w:) Th. Sutter-Somm, V. Harsági (Hrsg.), Die Entwicklung des Zivilprozessrechts in Mitteleuropa um die Jahrtausendwende. Reform und Kodifikation - Tradition und Erneuerung, Zürich-Basel-Genf 2012, s. 189 i n.; A. Góra-Błaszczykowska (red.), Nowelizacja Kodeksu postępowania cywilnego, Sopot 2015; J. Bieluk, A. Marciniak (red.), Postępowanie i prawo cywilne w dobie informatyzacji, Sopot 2016.

14 T. Ereciński, O uwarunkowaniach, potrzebie oraz zakresie nowego kodeksu postępowania cywilnego, „Polski Proces Cywilny" 2010, nr 1, s. 11 i n.; T. Ereciński, Dalsze zmiany czy nowy Kodeks postępowania cywilnego? (w:) K. Markiewicz (red.), Reforma postępowania cywilnego $w$ świetle projektów Komisji Kodyfikacyjnej, Warszawa 2011, s. 3 i n.; K. Markiewicz, Zagadnienia legislacyjne w pracach nad przyszłym kodeksem postępowania cywilnego (w:) W. Brzozowski, A. Krzywoń (red.), Leges ab omnibus intellegi debent. Księga $X V$-lecia Rzadowego Centrum Legislacyjnego, Warszawa 2015, s. 272-273. 
instytucji procesowych, uwzględniających również aspekty prawnoporównawcze ${ }^{15}$, lecz nabierały charakteru koncepcyjnego i systemowego, co znajdowało ten przebiegał spokojnie, bez zbędnego pośpiechu, ale systematycznie, będąc działaniem obliczonym raczej na dłuższą niż krótszą perspektywę czasową.

\title{
Proces reformowania polskiego prawa procesowego
} cywilnego, zainicjowany pod koniec roku

\author{
1989 i kontynuowany następnie przez około
}

ćwierć wieku, oraz zapoczątkowane w 2011 r.

prace nad przygotowaniem projektu nowego

Kodeksu postępowania cywilnego wiązały się

z funkcjonowaniem Komisji Kodyfikacyjnej Prawa

Cywilnego działającej przy Ministrze Sprawiedliwości.

wyraz w rozważaniach na temat struktury, zakresu przedmiotowego i konstrukcji nowej kompleksowej ustawy procesowej ${ }^{16}$. Można postawić tezę, że proces

15 Tytułem przykładu zob. A. Jakubecki, Zdolność sq̨dowa według kodeksu postępowania i przepisów odrębnych (de lege lata $i$ de lege ferenda) (w:) K. Markiewicz, A. Torbus (red.), Postępowanie rozpoznawcze w przyszłym Kodeksie postępowania cywilnego, Warszawa 2014, s. 79 i n.; Ł. Błaszczak, Wadliwość czynności procesowych stron i uczestników. Obecny model i propozycja zmian w przyszłym Kodeksie postępowania cywilnego (w:) K. Markiewicz, A. Torbus (red.), Posteppowanie rozpoznawcze..., s. 173 i n.; P. Grzegorczyk, Dopuszczalność $i$ ksztalt apelacji w postępowaniu cywilnym - perspektywy przyszłej regulacji z uwzględnieniem standardów konstytucyjnych i międzynarodowych (w:) K. Markiewicz, A. Torbus (red.), Postępowanie rozpoznawcze..., s. 219 i n.; K. Weitz, Skarga o wznowienie postępowania w przyszłym Kodeksie postępowania cywilnego (w:) K. Markiewicz, A. Torbus (red.), Postępowanie rozpoznawcze..., s. 323 i n.

16 Por. przykładowo M. Walasik, Zakres regulacji nowego Kodeksu postępowania cywilnego (w:) K. Markiewicz, A. Torbus (red.), Postępowanie rozpoznawcze w przyszłym Kodeksie postępowania cywilnego, Warszawa 2014, s. 43 i n.; K. Lubiński, Teoretyczne a legislacyjne podstawy przekazywania
Podkreślić należy, że zarówno cały proces reformowania polskiego prawa procesowego cywilnego, zainicjowany pod koniec roku 1989 i kontynuowany następnie przez około ćwierć wieku, jak również zapoczątkowane w 2011 r. prace nad przygotowaniem projektu nowego Kodeksu postępowania cywilnego ${ }^{17}$ nieodłącznie wiązały się z funkcjonowaniem Komisji Kodyfikacyjnej Prawa Cywilnego działającej przy Ministrze Sprawiedliwości ${ }^{18}$. Komisja ta, nawiązująca do tradycji Komisji Kodyfikacyjnej Rzeczypospolitej

spraw do procesu i postępowania nieprocesowego w nowym Kodeksie postępowania cywilnego (w:) E. Marszałkowska-Krześ, I. Gill, Ł. Błaszczak 9red.), Kodeks postępowania cywilnego z perspektywy pięćdziesięciolecia jego obowiązywania. Doświadczenia i perspektywy, Sopot 2016, s. 21 i n.

17 Zob. T. Ereciński, Wprowadzenie. O stanie prac nad projektem nowego Kodeksu postępowania cywilnego (w:) K. Markiewicz, A. Torbus (red.), Postępowanie rozpoznawcze..., s. 3 i n.

18 Komisja ta zaczęła działać w dniu 5 grudnia 1996 r., por. Komisja Kodyfikacyjna Prawa Cywilnego, „Kwartalnik Prawa Prywatnego" 1997, z. 2, s. 319 i n. Jej poprzedniczką była Komisja ds. Reformy Prawa Cywilnego, która opracowała projekty zmian Kodeksu postępowania cywilnego przyjęte wcześniej, w tym reformy przeprowadzonej w 1996 r. 
Polskiej ${ }^{19}$, działającej w okresie międzywojennym, oraz doświadczeń różnych powojennych komisji kodyfikacyjnych $^{20}$, opracowywała na bieżąco projekty legislacyjne znacznej części kolejnych nowelizacji kodeksu i jednocześnie podjęła prace koncepcyjne nad przygotowaniem projektu nowej kodyfikacji procesowej ${ }^{21}$. Była polem współdziałania przedstawicieli doktryny i praktyki oraz realizowała stawiane przed nią zadania niezależnie od zmian kolejnych ekip politycznych, aż do chwili jej nagłego i nigdy rzeczowo nieumotywowanego odwołania w grudniu 2015 r. $^{22}$

Ostatnie lata nie zahamowały wprowadzania dalszych zmian obowiązującego kodeksu. Dotknęły one zarówno regulacji postępowania rozpoznawczego ${ }^{23}$,

19 Na temat przedwojennej Komisji Kodyfikacyjnej RP por. np. L. Górnicki, Prawo cywilne w pracach Komisji Kodyfikacyjnej Rzeczypospolitej Polskiej w latach 1919-1939, Wrocław 2000, s. 12-57.

20 Na temat tych komisji por. m.in. A. Machnikowska, 50-lecie..., s. 561-573.

21 Zob. sprawozdania z działalności Komisji za kolejne lata (2011, 2012, 2013, 2014 i 2015) dostępne na stronie Ministerstwa Sprawiedliwości (https://www.gov.pl/web/sprawiedliwosc/komisja-kodyfikacyjna-prawa-cywilnego; dostęp 7.02.2020) i publikowane na łamach „Kwartalnik Prawa Prywatnego" (2012, z. 2, s. 563 i n.; 2013, z. 2, s. 513 i n.; 2014, z. 2, s. 473 i n.; 2015, z. 2, s. 463 i n.; 2016, z. 2, s. 451 i n.). Efekty tych prac zostały wykorzystane m.in. w zbiorze rozpraw powołanym w przypisie 10. Por. także M. Walasik, K. Markiewicz, Założenia wstępne dotyczące przepisów o postępowaniu nieprocesowym w nowym Kodeksie postępowania cywilnego przyjęte przez zespót problemowy Komisji Kodyfikacyjnej Prawa Cywilnego do spraw postępowania cywilnego, „Przegląd Sądowy” 2012, nr 9, s. 101 i n.; K. Markiewicz, A. Torbus, I. Wolwiak, Założenia doręczeń w postępowaniu cywilnym, „Polski Proces Cywilny” 2014, $\mathrm{nr} 2$, s. 301 i n.; K. Markiewicz, Właściwość sądu, skład sądu i wyłaczenie sędziego w pracach Komisji Kodyfikacyjnej Prawa Cywilnego, „Polski Proces Cywilny” 2015, nr 2, s. 278 i n.

22 Por. informację na stronie Ministerstwa Sprawiedliwości, https://www.gov.pl/web/sprawiedliwosc/komisja-kodyfikacyjna-prawa-cywilnego (dostęp 7.02.2020).

23 Największe zmiany w tym zakresie wynikają z przepisów ustawy z dnia 4.07.2019 r. o zmianie ustawy - Kodeks postępowania cywilnego oraz niektórych innych ustaw, Dz.U. poz. 1469 ze zm. jak również postępowania egzekucyjnego ${ }^{24}$. Cechą charakterystyczną okresu od końca 2015 r. pozostaje jednak to, że projekty nowelizacji przepisów procesowych w sprawach cywilnych opracowywane są w innych uwarunkowaniach ${ }^{25}$, w wyraźnej, niemal zamierzonej ${ }^{26}$ opozycji do świata nauki prawa postępowania cywilnego, bez uwzględniania - mimo ich przedstawiania - krytycznych głosów płynących ze środowiska prawniczego ${ }^{27}$. Efekty tych najnowszych zmian stanowią przedmiot ożywionej dyskusji przedstawicieli doktryny oraz praktyki, podchodzących z jednej strony w dość zróżnicowany sposób do oceny poszczególnych nowych rozwiązań proceso$w_{y c h}{ }^{28}$, a z drugiej strony wyrażających poważne obawy o kondycję Kodeksu postępowania cywilnego jako ustawy fundamentalnej dla funkcjonowania i sprawności wymiaru sprawiedliwości w sprawach cywilnych $^{29}$. Znamienne jest również to, że niemal zamilkła dyskusja procesualistów na temat możliwości przygotowania projektu nowego kodeksu ${ }^{30}$. Nowym

24 Por. przykładowo zmiany wynikające $\mathrm{z}$ art. 261 ustawy z dnia 22.03.2018 r. o komornikach sądowych, Dz.U. poz. 771 ze zm.

25 Zwrócił na to uwagę m.in. K. Markiewicz, Właściwość iskład sądu (w:) K. Markiewicz, A. Torbus (red.), Podmioty w postępowaniu cywilnym, Warszawa 2018, s. 16-17.

26 Takie podejście było anonsowane przez Ł. Piebiaka (Czym jest proces cywilny?, „Rzeczpospolita”, 17.12.2013, s. C 7), Podsekretarza Stanu w Ministerstwie Sprawiedliwości w latach 2015-2019.

27 Por. krytykę przywrócenia postępowania odrębnego w sprawach gospodarczych ze strony A. Jakubeckiego, Czy potrzebne jest nam postępowanie odrębne w sprawach gospodarczych? (uwagi na tle projektu ustawy o zmianie ustawy - Kodeks postępowania cywilnego z 13 września 2018 r.), „Radca Prawny ZN” 2018, nr 4, s. 53 i n.

28 Por. m.in. T. Zembrzuski (red.), Kodeks postępowania cywilnego. Koszty sadowe w sprawach cywilnych. Dochodzenie roszczeń w postępowaniu grupowym. Przepisy przejściowe. Komentarz do zmian, Warszawa 2019.

29 Zob. przykładowo P. Rylski, O nowelizacji Kodeksu postępowania cywilnego ustawa z 4.07.2019 r. wogólności, „Palestra” 2019, nr 11-12, s. 15 i n.

30 Pokłosiem prac dawnej Komisji Kodyfikacyjnej pozostają jednak wypowiedzi procesualistów odnoszące się do zagadnień szczegółowych, które były wcześniej przedmiotem wstępnych prac Komisji, por. m.in. K. Markiewicz, Właściwość..., 
czynnikiem jest okoliczność, że ostatnie zmiany pozostają jedynie w tle i na drugim planie w stosunku do postępującego procesu dekompozycji ustrojowej sądów i władzy sądowniczej w Polsce, co wyznacza - jako bardzo istotny element - nowy, dodatkowy punkt odniesienia w dyskusji nad obecnym stanem prawa postępowania cywilnego.

2. Spojrzenie na zagadnienie aktualnych problemów kodyfikacji prawa procesowego cywilnego w Polsce wymaga uwzględnienia dwojakiego rodzaju okoliczności determinujących ocenę potrzeby i możliwości podjęcia, prowadzenia oraz finalizacji prac nad projektem nowej, kompleksowej ustawy procesowej, odpowiadającej kryteriom kodeksowym.

Z jednej strony chodzi o aktualny stan obowiązującego dotąd kodeksu postępowania cywilnego, jego zdatności do dalszego funkcjonowania i adaptacji w przypadku poddania go kolejnym niezbędnym nowelizacjom, potrzebę uwzględniania współczesnych wyzwań legislacyjnych będących skutkiem procesów konstytucjonalizacji, europeizacji oraz informatyzacji prawa procesowego cywilnego i stałego wzrostu napływu spraw cywilnych do sądów, w tym spraw o charakterze masowym, a także problem postępującej coraz szybciej intensyfikacji stosunków społecznych i gospodarczych implikującej w dużej mierze zmienność prawa w ogóle, w tym prawa sądowego.

$\mathrm{Z}$ drugiej strony trzeba wziąć pod uwagę obecne uwarunkowania społeczno-polityczne, z którymi mamy do czynienia w naszym kraju i których wyrazem jest dewastacja kultury tworzenia prawa, w tym w szczególności na etapie prac parlamentarnych. Przykładem są procesy legislacyjne w dziedzinie prawodawstwa procesowego oraz ustrojowego w zakresie sądownictwa, tzw. reforma wymiaru sprawiedliwości

s. 15 i n.; M. Dziurda, Zdolność sądowa i jej znaczenie (w:) K. Markiewicz, A. Torbus (red.), Podmioty w postępowaniu cywilnym, Warszawa 2018, s. 133 i n.; A. Jakubecki, Zdolność procesowa $w$ Kodeksie postępowania cywilnego (de lege lata $i$ de lege ferenda) - wybrane zagadnienia (w:) K. Markiewicz, A. Torbus (red.), Podmioty w posteppowaniu cywilnym, s. 159 i n.; K. Gajda-Roszczynialska, Między prokuratorem a organizacjami pozarządowymi-udział podmiotów innych niż materialnie uprawnione (uwagi de lege lata $i$ de lege ferenda) (w:) K. Markiewicz, A. Torbus (red.), Podmioty w postępowaniu cywilnym, s. $177 \mathrm{i} \mathrm{n}$. w jej obecnym i możliwym przyszłym kształcie - niemogąca pozostać bez wpływu na perspektywę ewentualnej kodyfikacji prawa postępowania cywilnego - oraz postępująca instrumentalizacja tego prawa łącząca się z populizmem prawniczym.

Pierwsza grupa wymienionych okoliczności wpływa na ocenę tego, czy pożądane jest przygotowanie w dającej się realnie przewidzieć perspektywie czasowej projektu nowego Kodeksu postępowania cywilnego, natomiast druga odnosi się do tego, czy przeprowadzenie takiego przedsięwzięcia jest aktualnie obiektywnie możliwe i wskazane bez uszczerbku dla ewentualnego rezultatu.

3. Pozostając w niniejszym opracowaniu na poziomie rozważań o charakterze ogólnym i kierunkowym podtrzymać należy - jako punkt wyjścia - założenie, że kodeksy są ustawami o podstawowym znaczeniu dla danej gałęzi prawa, które - w klasycznym ujęciu cechować powinna stabilność i trwałość ${ }^{31}$. Stabilność kodeksu oznacza, że jego uregulowania powinny być zmieniane najrzadziej, jak to jest możliwe. Współcześnie założenie o stabilności kodeksu jest coraz trudniej realizować, gdyż następuje intensyfikacja rozwoju stosunków społecznych i gospodarczych i ich globalizacja, co wpływa na rosnącą potrzebę ingerencji ustawodawcy w regulacje kodeksowe. Właściwe pozostaje jednak podejście, że - na tyle, na ile jest to możliwe - zmiany kodeksu powinny być ograniczane do takich, które są rzeczywiście niezbędne. Z kolei trwałość kodeksu należy rozumieć jako założenie, że tworzony jest on jako ustawa na długi czas, a więc także decyzja o jego zastąpieniu nową regulacją musi mieć mocne uzasadnienie i realne podstawy wynikające z potrzeb obrotu prawnego ${ }^{32}$.

Przyjęte swego czasu w polskiej nauce niemal zgodnie stanowisko, że obowiązujący kodeks postępowania powinien być zastąpiony nowym aktem prawnym, uzasadnione było tym, że nie można mówić już dłużej o aktualności w stosunku do niego założenia o jego trwałości. Wyrazem tego podejścia były głosy o tym, że na skutek wielu przeprowadzonych nowelizacji stał się on aktem niespójnym, wewnętrznie sprzecznym, kazuistycznym i skomplikowanym w praktycznym

31 K. Weitz, Czy nowa..., s. 21.

32 Tamże, s. 21-22. 
funkcjonowaniu, jak również niezdatnym do poddawania go kolejnym zmianom zgodnie ze współczesnymi wyzwaniami stojącymi przed prawem procesowym cywilnym ${ }^{33}$. Spojrzenie na ten aspekt oceny kondycji obowiązującego Kodeksu postępowania cywilnego w jego obecnym kształcie po kilku kolejnych latach pozwala na stwierdzenie, że podejście to nie tylko zachowało pełną aktualność, lecz znalazło dodatkowe potwierdzenie w pogłębiających się procesach degradacji kodeksu jako aktu prawnego. Ważnym elementem tych procesów stały się ostatnie nowelizacje kodeksu ${ }^{34}$, które - niezależnie od swojego zróżnicowanego charakteru - poważnie przyczyniły się do jego dekompozycji nie tylko w płaszczyźnie konstrukcyjnej i instytucjonalnej ${ }^{35}$,

33 Do tego wspólnego mianownika - mimo pewnej różnicy prezentowanych ujęć - można sprowadzić odnośne wypowiedzi doktryny, zob. T. Ereciński, O potrzebie..., s. 8-9; T. Ereciński, O uwarunkowaniach..., s. 11; T. Ereciński, Dalsze zmiany..., s. 5 i n.; F. Zedler, Co dalej..., s. 311-327; K. Weitz, Czy nowa..., s. 22-23.

34 Dotyczy to przede wszystkim nowelizacji dokonanej ustawą z dnia 4 lipca 2019 r., por. przypis 23.

35 Przejawem dekompozycji konstrukcyjnej jest wprowadzenie instytucji posiedzenia przygotowawczego i planu rozprawy, które są wyrazem (możliwego) podziału postępowania rozpoznawczego na etap przygotowawczy oraz (ewentualny) etap zmierzający do merytorycznego rozpoznania sprawy (rozprawy), podczas gdy obecny kodeks - wzorem kodeksu postępowania cywilnego z 1930 r. - skonstruowany został przy założeniu, że fazowość tego rodzaju nie jest elementem struktury postępowania rozpoznawczego, a funkcję przygotowawczą w stosunku do ustnej rozprawy spełnia - poza pozwem i odpowiedzią na pozew - ewentualna wymiana pism przygotowawczych, por. bliżej J.J. Litauer, Polska Procedura Cywilna. Projekty uchwalone przez Komisję Kodyfikacyjna. Kodeks postępowania cywilnego. Ustawa o wprowadzeniu kodeksu. Ustawa o kosztach sądowych. Uzasadnienie ogólne i tekst projektów, Warszawa 1930, s. 16. Przykładem dekompozycji instytucji procesowych są nowe rozwiązania odnoszące się do zażalenia, zob. T. Zembrzuski, Zażalenie po nowelizacji, czyli o standardzie środka zaskarżenia, „Palestra” 2019, nr 11-12, s. 242 i n., a także - choć w mniejszym stopniu - apelacji, zob. P. Rylski, Zmiany w przepisach o postępowaniu apelacyjnym $w$ świetle ale także językowej ${ }^{36}$, i podważyły jego rangę jako ustawy kodeksowej.

Trzeba mieć naturalnie świadomość wzrastającej szybkości rozwoju oraz zmienności stosunków prawnych w dziedzinie prawa prywatnego, którego normy realizowane są dzięki prawu procesowemu cywilnemu. Implikuje to nieustanną zmienność odnośnych regulacji, co w naturalny sposób dotyka przepisów ustawy procesowej. Należy się jednak spodziewać, że proces ten będzie raczej podlegał intensyfikacji i trudno może być w przyszłości o osiągnięcie w tym zakresie określonego poziomu stabilizacji, pozwalającego na pewne „zatrzymanie” sytuacji, w której założona zmienność prawa nie będzie stanowić przeciwwskazania dla podjęcia dzieła przygotowania nowej kodyfikacji procesowej. W ewentualnym sporze o to, czy - z tego tylko punktu widzenia - aktualne pozostaje stanowisko opowiadające się za przygotowaniem takiej kodyfikacji, czy też należy na trwałe zamiar taki porzucić, zdecydowanie opowiedzieć się należy za pierwszym podejściem. Generalizując problem - wydaje się, że współcześnie nie należy porzucać idei kodyfikowania gałęzi prawa jako takiej w razie stwierdzenia, że zachodzi rzeczywista potrzeba zastąpienia starego kodeksu nowym aktem prawnym. W dziedzinie prawa procesowego cywilnego założenie to potwierdza fakt przygotowania nowych kodeksów prawa postępowania cywilnego (prawa procesowego cywilnego) w innych państwach ${ }^{37}$. Stale dążąc do zachowania

modelu apelacji cywilnej, „Polski Proces Cywilny” 2020, nr 1, s. 119 i n.

36 Dobitnym tego dowodem jest zerwanie w wielu miejscach $\mathrm{z}$ tradycją formułowania jasnych i syntetycznych przepisów na rzecz regulacji, które są z jednej strony nadmiernie kazuistyczne, przez co przypominają „instrukcję obsługi”, a z drugiej strony - przez tę kazuistykę - niewolne od licznych luk. Niechlubnym przykładem w tym zakresie jest znowu regulacja posiedzenia przygotowawczego i planu rozprawy; na podobną ocenę zasługuje też - łącznie traktowany - zespół przepisów dotyczących nadużycia prawa procesowego.

37 Obok jednolitego szwajcarskiego Kodeksu postępowania cywilnego z 2008 r. wskazać można przykładowo na nowy brazylijski kodeks postępowania cywilnego z 2015 r., por. M.A. Feijó, R.L. Kochem, What to Expect from the new 
maksymalnej stabilizacji prawa i pozostając przy tezie, że stabilność kodeksu powinna być traktowana poważnie, trzeba pogodzić się z tym, że jej stopień może (będzie) w przyszłości ulegać nieustannemu zmniejszaniu. Trzeba wobec tego myśleć o przygo- tach - prawa postępowania cywilnego i postępujący wzrost napływu spraw cywilnych do sądów, w tym spraw typowych i podobnych lub masowych, wymagających rozwiązań pozwalających na ochronę interesów zbiorowych ${ }^{38}$.

\title{
Podtrzymując pogląd o potrzebie nowej
} Kodyfikacji prawa postępowania cywilnego

\section{w Polsce stwierdzić należy, że punktem odniesienia}

\section{dla podjęcia prac w tym względzie powinno}

być zdefiniowane zasadniczych wyzwań, które

\author{
należałoby $w$ ramach tych prac brać pod uwagę.
}

towaniu kodeksu, który będzie w pełni realizował założenie o jego trwałości i - w miarę możliwości w niezbędnym zakresie zachowa określoną stabilność.

Podtrzymując pogląd o potrzebie nowej kodyfikacji prawa postępowania cywilnego w Polsce stwierdzić należy - nie wnikając w zagadnienie szczegółowych rozwiązań, zakresu przedmiotowego i struktury nowego kodeksu - że punktem odniesienia dla podjęcia prac w tym względzie powinno być zdefiniowane zasadniczych wyzwań, które należałoby w ramach tych prac brać pod uwagę. Chodzi o wyzwania współczesnego prawa postępowania cywilnego, które wyznaczać powinny podstawowe kierunki reformowania tego prawa w ogólności, a tym samym - w wypadku przygotowywania nowej kodyfikacji - również determinować jej kształt w najbardziej ogólnych ramach. Do rzędu takich wyzwań zaliczyć należy aktualnie proces konstytucjonalizacji prawa postępowania cywilnego, wpływ, w różnych płaszczyznach, prawa Unii Europejskiej na prawo postępowania cywilnego, ze szczególnym uwzględnieniem procesu jego europeizacji, proces informatyzacji - w różnych aspek-

Brazilian Civil Procedure Code of 2015, „ZZP International” 2015, t. 20, s. 363 i n.
Szeroko pojęty wpływ prawa konstytucyjnego na prawo postępowania cywilnego jest dostrzegany w nauce krajowej ${ }^{39}$ i obcej ${ }^{40}$. Oddziałuje ono zarówno na wykładnię i stosowanie prawa postępowania cywilnego, jak i na jego tworzenie. Nauka zgodnie podnosi, że w ramach ewentualnych prac nad nowym Kodeksem postępowania cywilnego jednym z pod-

38 K. Weitz, Wplyw prawa Unii Europejskiej na krajowe prawo procesowe cywilne, „Kwartalnik Prawa Prywatnego” 2019, z. 2, s. 299-300.

39 P. Grzegorczyk, O konstytucjonalizacji prawa procesowego cywilnego, „Kwartalnik Prawa Prywatnego” 2012, z. 2 , s. 293 i n. Por. też T. Ereciński, K. Weitz (red.), Orzecznictwo Trybunału Konstytucyjnego a Kodeks postępowania cywilnego. Materiały Ogólnopolskiego Zjazdu Katedr i Zakładów Postępowania Cywilnego, Serock k. Warszawy, 24-26 września 2009 r., Warszawa 2010; P. Pogonowski, Wpływ wejścia w życie Konstytucji RP z 1997 r. na sadowe postępowanie cywilne (w:) Czterdziestolecie Kodeksu postępowania cywilnego. Zjazd Katedr Postępowania Cywilnego w Zakopanem (7.-9.10.2005 r.), Kraków 2006, s. 227 i n.; zbiór rozpraw Ł. Błaszczak (red.), Konstytucjonalizacja postępowania cywilnego, Wrocław 2015.

40 Por. literaturę powołaną przez P. Grzegorczyka, O konstytucjonalizacji..., s. 295-296. 
stawowych założeń musi być uwzględnienie procesu konstytucjonalizacji prawa procesowego cywilnego ${ }^{41}$. $\mathrm{Z}$ jednej strony regulacje konstytucyjne wyznaczają granice dla swobody tzw. ustawodawcy zwykłego w kształtowaniu postępowań sądowych, określając stytucyjne gwarancje do rozpoznania każdej sprawy w jawnym postępowaniu, bez nieuzasadnionej zwłoki, przez właściwy, niezależny, bezstronny i niezwisły sąd (art. 45 ust. 1 Konstytucji RP) ${ }^{43}$ i zakaz zamykania drogi sądowej dochodzenia naruszonych wolności

\section{Do wyzwań zaliczyć należy proces konstytucjonalizacji} prawa postępowania cywilnego, wpływ na to prawo prawa Unii Europejskiej, proces jego informatyzacji i postępujący wzrost napływu spraw cywilnych do sądów, w tym spraw typowych lub masowych, wymagających rozwiązań pozwalających na ochronę interesów zbiorowych.

podstawowe standardy, których należy dochować przy przyjmowaniu unormowań dotyczących wybranych konstrukcji. Z drugiej strony tworzenie nowej ustawy procesowej może być okazją do silniejszego osadzenia postępowania cywilnego na aktualnej konstytucyjnej podstawie, co ma znaczenie wobec faktu, że obowiązujący obecnie Kodeks postępowania cywilnego powstał w warunkach społeczno-ustrojowych radykalnie odmiennych od tych, które kształtuje Konstytucja RP z 1997 r. $^{42}$ Nie dezaktualizuje tego założenia obecny kryzys ładu konstytucyjnego w Polsce, wypływający ze sfery funkcjonowania państwa w płaszczyźnie politycznej, gdyż od strony formalnoprawnej za punkt odniesienia nadal należy uznawać porządek prawny wynikający z Konstytucji RP, a nie praktyczną jego odsłonę, którą da się współcześnie zaobserwować.

Przy kształtowaniu nowej kodyfikacji postępowania cywilnego uwzględnić należy, co oczywiste, kon-

41 F. Zedler, Co dalej..., s. 312; T. Ereciński, O uwarunkowaniach..., s. 15-16; K. Weitz, Czy nowa..., s. 23-24.

42 K. Weitz, Czy nowa..., s. 24; P. Grzegorczyk, O konstytucjonalizacji..., s. 329. i praw (art. 77 ust. 2 Konstytucji RP) ${ }^{44}$. Przekłada się to nie tylko na potrzebę odpowiedniej regulacji problematyki dopuszczalności drogi sądowej w postępowaniu cywilnym ${ }^{45}$ i ochrony prawa do wysłucha$n^{4}{ }^{46}$, ale także krytycznego spojrzenia na problem jawności postępowania w aspekcie zewnętrznym

43 Szczegółowo por. P. Grzegorczyk, K. Weitz (w:) M. Safjan, L. Bosek (red.), Konstytucja RP. Komentarz, t. 1, Warszawa 2016, art. 45, nb. 1-123, s. 1079-1152.

44 O rozumieniu tego zakazu i jego relacji do prawa do sądu w ujęciu art. 45 Konstytucji RP zob. P. Grzegorczyk, K. Weitz (w:) Konstytucja RP..., art. 77, nb. 128-144, s. 1774-1784.

45 Por. dotąd nieuwzględnione przez ustawodawcę orzecznictwo Sąd Najwyższego dotyczące dopuszczalności drogi sądowej w kontekście domniemania właściwości sądów powszechnych i Sądu Najwyższego w ujęciu art. 177 Konstytucji RP. Chodzi o postanowienia z dnia 21 maja 2002 r., III CK 53/02, OSNC 2003, nr 2, poz. 31, i z dnia 19 grudnia 2003 r., III CK 319/03, OSNC 2005, nr 2, poz. 31.

46 O treści prawa do wysłuchania, jego konstytucyjnym umocowaniu i realizacji w postępowaniu cywilnym zob. P. Grzegorczyk, K. Weitz (w:) Konstytucja RP..., art. 45, nb. 95-97, s. 1132-1136. 
(art. 45 ust. 2 Konstytucji RP) ${ }^{47}$. Ważne znaczenie ma również zasada zaskarżalności orzeczeń wydanych w pierwszej instancji (art. 78 Konstytucji RP) ${ }^{48}$ i ustrojowa zasada dwuinstancyjności postępowania sądowego (art. 176 ust. 1 Konstytucji RP) ${ }^{49}$. Chodzi o prawidłowe odczytanie tych zasad, możliwości przyjęcia wyjątków od zaskarżalności orzeczeń wydanych w pierwszej instancji oraz transpozycję właściwie rozumianej ustrojowej zasady, że postępowanie sądowe jest dwuinstancyjne. Uregulowania konstytucyjne trzeba ponadto brać pod uwagę w kontekście rozwiązań szczegółowych, w tym przy ocenie, czy niektóre z obecnie istniejących rozwiązań powinny w jakimś zakresie być transponowane do nowego kodeksu (np. kwestia udziału prokuratora $\mathrm{w}$ postępowaniu cywilnym) ${ }^{50}$.

Wpływ prawa Unii Europejskiej na krajowe prawo procesowe cywilne przejawia się na trzech współistniejących płaszczyznach ${ }^{51}$. Pierwsza płaszczyzna obejmuje oddziaływanie na to prawo statuowanych w unijnym prawie pierwotnym podstawowych swobód, ogólnego zakazu dyskryminacji oraz procesowych praw podstawowych. W drugiej płaszczyźnie chodzi o funkcjonowanie prawodawstwa unijnego w dziedzinie procesowej w łączności z krajowym prawem procesowym cywilnym. Trzecia z kolei płaszczyzna dotyczy realizacji prawa unijnego $\mathrm{w}$ otoczeniu unormowań krajowego prawa procesowego ${ }^{52}$. Wpływ ten odnosi

47 K. Weitz (w:) T. Ereciński (red.), Kodeks postępowania cywilnego. Komentarz, t. 1, Postępowanie rozpoznawcze, Warszawa 2016, art. 9, uw. 2, s. 200. O ograniczeniach jawności zewnętrznej w ustawie z dnia 4 lipca 2919 r. por. A. Gołąb, Wybrane aspekty zasady jawności w świetle nowelizacji Kodeksu postępowania cywilnego z 4.7.2019 r. (w:) P. Rylski (red.), Ustawa z 4.7.2019 r. - reforma czy kolejna nowelizacja KPC?, Warszawa 2020, s. 107 i nast.

48 O wykładni tej zasady na poziomie konstytucyjnym i możliwych jej ograniczeniach również w postępowaniu sądowym zob. P. Grzegorczyk, K. Weitz (w:) Konstytucja RP..., art. 78, nb. 1-89, s. 1785-1819.

49 Bliżej por. P. Grzegorczyk (w:) M. Safjan, L. Bosek (red.), Konstytucja RP. Komentarz, t. 2, Warszawa 2016, art. 176, nb. 1-27, s. 983-1001.

50 P. Grzegorczyk, O konstytucjonalizacji.., s. 333.

51 K. Weitz, Wpływ..., s. 298.

52 Tamże, s. 298-299. się nie tylko do sfery stosowania krajowego prawa procesowego (działalności sądów krajowych będących też sądami unijnymi), lecz także do sfery jego tworzenia (działalności legislatora krajowego) ${ }^{53}$. W rezultacie nie budzi wątpliwości, że przygotowanie projektu nowej ustawy procesowej powinno mieć - jako jeden z zasadniczych punktów odniesienia - wspomniany wpływ prawa unijnego na krajowe prawo postępowania cywilnego ${ }^{54}$, przy założeniu, że kontynuacja przynależności naszego kraju do Unii Europejskiej nie jest i nie będzie stawiana również w przyszłości pod jakimkolwiek znakiem zapytania.

O ile pierwsza z wyróżnionych płaszczyzn oddziaływania prawa unijnego wykazuje w decydującej mierze podobieństwo do wpływu prawa konstytucyjnego na prawo postępowania cywilnego ${ }^{55}$, o tyle na szczególną uwagę zasługuje druga z tych płaszczyzn, przejawiająca się $\mathrm{w}$ stanowieniu przez prawodawcę unijnego regulacji procesowych, które mają funkcjonować w łączności z krajowymi regulacjami procesowymi. Taka aktywność prawodawcy unijnego w każdym wypadku stawia prawodawcę krajowego przed zagadnieniem rozważania celowości ewentualnego uzupełnienia (w wypadku rozporządzeń unijnych) lub koniecznością wykonania obowiązku transpozycji (w wypadku dyrektyw) regulacji prawa unijnego na grunt krajowego porządku prawnego ${ }^{56}$. W kontekście projektowania nowego Kodeksu postępowania cywilnego chodzi w pierwszej kolejności o technikę rozwiązania w jego ramach dylematu, czy należy odpowiednie regulacje umiejscawiać, jeśli nie znajdą się one w oddzielnych ustawach, w rożnych częściach kodeksu, czy też skupić je w jednej jego części, poświęconej wyłącznie wypadkom, w których chodzi o uzupełnienie lub transpozycję prawa unijnego. Wydaje się, że kierunkowo należy opowiedzieć się za drugim podejściem, z zastrzeżeniem jednak sytuacji, w których nie będzie to możliwe lub okazałoby się niefunkcjonalne. Podejście to jest pożądane przede wszystkim w zakresie uzupełniania lub transpozycji

53 Tamże, s. 299.

54 K. Weitz, Czy nowa..., s. 24; T. Ereciński, O uwarunkowaniach..., s. 16-17; T. Ereciński, Dalsze zmiany..., s. 6; T. Ereciński, Wprowadzenie. O stanie..., s. 4.

55 K. Weitz, Wpływ..., s. 305-306.

56 Tamże, s. 313-314. 
regulacji prawa unijnego przyjmowanych $\mathrm{w}$ dziedzinie współpracy sądowej w sprawach cywilnych.

Cechą charakterystyczną współczesności jest wzrastający wpływ na funkcjonowanie państwa i jego organów oraz na kształt prawa i jego stosowanie szeroko pojętego rozwoju nauki i techniki. Wymiar sprawiedliwości i jego organy oraz prawo postępowania sądowego, $\mathrm{w}$ tym prawo postępowania cywilnego, nie tylko nie są w tym zakresie jakimś wyjątkiem, lecz co bardzo istotne, powinny w sposób szczególny profitować $z$ tego rozwoju i pozostawać otwarte na jego rezultaty. Postępująca informatyzacja życia publicznego już odcisnęła swoje piętno na kształcie regulacji prawa procesowego cywilnego ${ }^{57}$ i nie ulega wątpliwości, że nie mogłaby pozostać bez istotnego wpływ na jego ewentualną nową kodyfikację, co zgodnie podkreślano $\mathrm{w}$ literaturze przedmiotu ${ }^{58}$. Zauważono w związku z tym, że nowy kodeks dawałby sposobność do tego, aby zamiast dokonywania w tym zakresie cząstkowych nowelizacji dotychczasowej ustawy procesowej, co nie przyniosło w pełni zadowalających rezultatów, stworzyć akt prawny, który stanowiłby nową jakość

57 K. Markiewicz, Informatyzacja postępowania cywilnego de lege lata $i$ de lege ferenda (w:) K. Markiewicz, A. Torbus (red.), Postępowanie rozpoznawcze w przyszłym Kodeksie postępowania cywilnego, Warszawa 2014, s. 403 i n.; K. Flaga-Gieruszyńska, J. Gołaczyński, D. Szostek (red.), Informatyzacja postępowania cywilnego. Teoria i praktyka, Warszawa 2016. Dużego postępu w tej dziedzinie nie przyniosła ustawa z 4. lipca 2019 r. Wagę procesu informatyzacji postępowania cywilnego i jednocześnie słabość regulacji obowiązującego kodeksu z tego punktu widzenia unaocznił okres pandemii COVID-19. Ustawodawca mógł w tym zakresie zareagować - z oczywistych względów - tylko częściowo, w sposób doraźny, por. art. 15 zzs$^{1}$ ustawy z dnia 2 marca 2020 r. o szczególnych rozwiązaniach związanych z zapobieganiem, przeciwdziałaniem i zwalczaniem COVID-19, innych chorób zakaźnych oraz wywołanych nimi sytuacjami kryzysowych (Dz. U. z poz. 374 ze zm.).

58 K. Weitz, Czy nowa..., s. 24; T. Ereciński, Dalsze zmiany..., s. 6-7; K. Markiewicz, Informatyzacja..., s. 436-440; J. Gołaczyński, Model informatyzacji postępowania cywilnego w nowym Kodeksie postępowania cywilnego (w:) K. Markiewicz, A. Torbus (red.), Postępowanie rozpoznawcze w przyszłym Kodeksie postępowania cywilnego, Warszawa 2014, s. 391 in. w dziedzinie otwarcia na postęp naukowo-techniczny i mógłby pozostawać podatny na adaptację do ewentualnych nowych osiągnięć wynikających z tego postępu w przyszłości ${ }^{59}$.

Proces informatyzacji prawa postępowania cywilnego, będąc współcześnie wyzwaniem dla rozwoju i funkcjonowania prawa procesowego cywilnego w ogólności ${ }^{60}$, musi być punktem odniesienia dla przygotowania nowej kodyfikacji tego prawa w Polsce. Wyróżnić można trzy kierunki tego procesu. Po pierwsze, chodzi o formę zachowań (np. czynności procesowych) organów prowadzących postępowanie i podmiotów uczestniczących w tym postępowaniu i ich wzajemne komunikowanie się (np. przez dokonywanie doręczeń). Po drugie, wskazać należy na wykorzystywanie nowoczesnych technologii w organizacji oraz funkcjonowaniu organów prowadzących postępowanie i przy utrwalaniu przebiegu postępowania (np. elektroniczne akta i elektroniczny protokół). Po trzecie, trzeba brać pod uwagę rozwój nowych technologii, sposobów komunikowania oraz utrwalania zdarzeń i ich przebiegu w kontekście dokonywania ustaleń faktycznych w postępowaniu dowodowym (np. nowe postaci dowodów).

Dotychczas tak rozumiana informatyzacja postępowania cywilnego realizowana była punktowo $\mathrm{w}$ drodze kolejnych nowelizacji ${ }^{61}$. Nowy kodeks powinien proces ten dopełnić. Konieczne jest przy tym takie jego skonstruowanie, aby informatyzacja $\mathrm{z}$ jednej strony została w nim uwzględniona w sposób całościowy, a z drugiej strony aby był on aktem możliwie

59 K. Weitz, Czy nowa..., s. 24.

60 Por. M. Kengyel (ed.), Electronic Justice - Present and Future. Colloquium of the International Association of Procedural Law Pécs, September 23-25, 2010, Pécs 2010. Tematykę tę podjęto ostatnio na XVI Światowym Kongresie Prawa Procesowego pod egidą International Association of Procedural Law (IAPL) w Kobe w dniach 2-5.11.2019 r., zatytułowanym Challenges for Civil Justice as We Move Beyond Globalization and Technical Change. Por. przedstawione na kongresie raporty generalne F. Verbic, Moon-hyuck HO, E. Sugiyamy i J. Picó-Junoy dotyczące stosowania technologii elektronicznych w postępowaniu sądowym i nowych typów dowodów.

61 Obok cytowanej już literatury zob. J. Gołaczyński, D. Szostek (red.), Informatyzacja postępowania cywilnego. Komentarz, Warszawa 2016. 
najbardziej „otwartym” na potencjalny przyszły dalszy rozwój nauki i techniki. Jakkolwiek w nauce przedmiot dyskusji stanowi kwestia, czy i w jakim stopniu proces informatyzacji prawa postępowania cywilnego wpływa na redefinicję oraz dotychczasowe pojmowanie zasad prawa procesowego cywilnego i jego różnych konstrukcji ${ }^{62}$, to nie ulega wątpliwości, że kierować się należy ogólnym założeniem, iż wszelkie ewentualne przeobrażenia w tym zakresie, jeżeli miałyby nastąpić, muszą respektować główne gwarancje i założenia postępowania cywilnego jako postępowania sądowego, w którym rozstrzyga się wiążąco o prawach i obowiązkach obywateli w ich wzajemnych relacjach ${ }^{63}$.

Rozwijająca się niezwykle szybko współczesna cywilizacja niesie za sobą nieustanny wzrost liczby zdarzeń będących źródłem spraw kierowanych do postępowania sądowego, które angażują coraz większą liczbę podmiotów. Często są to sprawy typowe i podobne, a ich znamienną cechą pozostaje fakt, że są konsekwencją masowości współczesnych zjawisk dotykających różnych interesów, nie tylko zindywidualizowanych, ale także bliżej nieokreślonych, w szczególności interesów o naturze zbiorowej. Z jednej strony wyzwaniem pozostaje to, jak rozwiązywać problemy, które wynikają ze wzrostu liczby spraw w sądach, przy zastosowaniu tradycyjnych mechanizmów procesowych i zwiększaniu efektywności funkcjonowania organów wymiaru sprawiedliwości w drodze zabiegów orga-

62 P. Calmon, The Future of the Traditional Civil Procedure (w:) M. Kengyel (ed.), Electronic Justice - Present and Future. Colloqium of the International Association of Procedural Law Pécs, September 23-25, 2010, Pécs 2010, s. 175 i n.; N. Fischer, Electronification of Civil Litigation and Civil Justice - The Future of the Traditional Civil Procedure facing the Electronification (w:) M. Kengyel (ed.), Electronic Justice - Present and Future. Colloqium of the International Association of Procedural Law Pécs, September 23-25, 2010, Pécs 2010, s. 217 i n.; A. Zalesińska, Wpływ informatyzacji na założenia konstrukcyjne procesu cywilnego, Warszawa 2016, passim.

63 K. Flaga-Gieruszyńska, Informatyzacja w świetle zasad postępowania cywilnego - wybrane zagadnienia (w:) E. Marszałkowska-Krześ, I. Gil, Ł. Błaszczak (red.), Kodeks postępowania cywilnego z perspektywy pięćdziesięciolecia jego obowiązywania. Doświadczenia i perspektywy, Sopot 2016, s. 344 . nizacyjnych ${ }^{64}$. Z drugiej strony uwzględnić należy potencjalny rozwój nowych form i metod udzielania ochrony sądowej, w szczególności zorientowanych na różne postaci ochrony interesów zbiorowych ${ }^{65}$. Problematyka ta stanowi od pewnego czasu przedmiot zainteresowania nauki prawa procesowego cywilnego poza obszarem jej tradycyjnego pola oddziaływania w państwach common law ${ }^{66}$. W naturalny sposób jest ona również podejmowana - jako stanowiąca samodzielne wyzwanie i niosąca ze sobą sobie właściwe konsekwencje w zakresie rozwiązań i konstrukcji procesowych - w kontekście przygotowania nowej kodyfikacji prawa postępowania cywilnego ${ }^{67}$.

$\mathrm{W}$ dotychczasowym rozwoju prawa procesowego cywilnego zagadnienie ochrony w jednym postępowaniu interesów wielu podmiotów, pomijając tradycyjną instytucję procesową w postaci współuczestnictwa procesowego, znalazło w naszym kraju odzwierciedlenie przede wszystkim ${ }^{68} \mathrm{w}$ ustawie o dochodzeniu roszczeń w postępowaniu grupowym ${ }^{69}$. Stanowiła ona ostrożny krok w kierunku unormowania przed-

64 Por. F. Zedler, Wybrane problemy wspótczesnego postępowania cywilnego (w:) E. Marszałkowska-Krześ, I. Gil, Ł. Błaszczak (red.), Kodeks postępowania cywilnego z perspektywy pięćdziesięciolecia jego obowiązywania. Doświadczenia i perspektywy, Sopot 2016, s. $15 \mathrm{i} \mathrm{n.}$

65 Por. R. Kulski, Ochrona interesów zbiorowych w postępowaniu cywilnym, Warszawa 2017, s. 1.

66 Zob. m.in. E. Oteiza (red.), Procesos colectivos/Class actions, Buenos Aires 2012. W publikacji zawarto referaty i wystąpienia przygotowane I Międzynarodową Konferencję International Association of Procedural Law oraz Jornadas Iberoamericanas de Derecho Procesal, która odbyła się w dniach 6-9 czerwca 2012 r. w Buenos Aires. Na temat tej konferencji por. także P. Grzegorczyk, K. Weitz, Sprawozdanie z I Międzynarodowej Konferencji Międzynarodowego Stowarzyszenia Prawa Procesowego i Iberoamerykańskiego Instytutu Prawa Procesowego Procesos Colectivos/Class Actions, Buenos Aires 6-9 czerwca 2012, „Polski Proces Cywilny” 2013, nr 1, s. 140-143. Por. ponadto R. Kulski, Ochrona..., s. 151 i n.

67 Tak. K. Weitz, Czy nowy..., s. 26; T. Ereciński, Dalsze zmiany..., s. 8 .

68 Co do innych regulacji por. R. Kulski, Ochrona..., s. 255 i n.

69 Ustawa z dnia 17.12.2009 r. o dochodzeniu roszczeń w postępowaniu grupowym, tj. Dz.U. 2018, poz. 573 ze zm. Na temat tej ustawy w jej pierwotnym kształcie por. np. P. Grzegorczyk, 
miotowej problematyki, umiejscowiony jednak poza obowiązującym obecnie Kodeksem postępowania cywilnego, poddany po pewnym czasie modyfikacjom $^{70}$. Za nierozstrzygniętą należy uznać kwestię, czy w przyszłości problematyka ochrony interesów zbiorowych w postępowaniu cywilnym powinna stać się $\mathrm{w}$ prawie polskim przedmiotem całościowego uregulowania, a jeśli tak, to czy uregulowanie to powinno pozostać odrębnym od kodeksu aktem prawnym, czy też stanowić jednak jego częśćc ${ }^{71}$. Wydaje się, że o ile trudno mówić o jednej wyczerpującej i całościowej regulacji całości problematyki interesów zbiorowych w postępowaniu cywilnym w jednym akcie prawnym, gdyż na przeszkodzie takiej regulacji stałaby złożoność tej problematyki ${ }^{72}$, o tyle za celowe należy uznać umieszczenie w nowej kodyfikacji procesowej - w odpowiednio zmodyfikowanej i rozwiniętej postaci - tych rozwiązań i konstrukcji procesowych, które składają się na jednoczesne dochodzenie roszczeń wielu podmiotów w jednym postępowaniu sądowym.

4. Wzgląd na aktualną kondycję obowiązującego Kodeksu postępowania cywilnego i potrzeba uwzględnienia wskazanych współczesnych wyzwań prawa procesowego cywilnego przemawiają wyraźnie - mimo nieuchronnego zmniejszania się stopnia stabilności regulacji prawnych - za podjęciem trudu opracowania nowej kodyfikacji. To, co stawia przed pytaniem, czy obecnie możliwe oraz celowe jest podjęcie takiego trudu bez ryzyka obniżenia jakości ostatecznego rezultatu, wiąże się z kryzysem kultury tworzenia prawa, właściwym polskiej praktyce szczególnie w ostatnich latach, z następstwami tzw. reformy wymiaru spra-

Ustawa o dochodzeniu roszczeń w postępowaniu grupowym. Ogólna charakterystyka, Warszawa 2011.

70 M. Rzewuska, Dochodzenie roszczeń w postępowaniu grupowym - stan obecny i perspektywy zmian (w:) E. Marszałkowska-Krześ, I. Gil, Ł. Błaszczak (red.), Kodeks postępowania cywilnego z perspektywy pięćdziesięciolecia jego obowiązywania. Doświadczenia i perspektywy, Sopot 2016, s. 515 i n.; P. Grzegorczyk, Postępowanie grupowe po reformie (w:) Honeste procedere. Księga jubileuszowa dedykowana Profesorowi Kazimierzowi Lubińskiemu, Warszawa 2017, s. $97 \mathrm{i} \mathrm{n.}$

71 Por. T. Ereciński, Dalsze zmiany..., s. 8; R. Kulski, Ochrona..., s. $450-451$.

72 R. Kulski, Ochrona..., s. 31 i n. wiedliwości oraz niebezpieczeństwami wynikającymi z postępującej instrumentalizacji prawa procesowego cywilnego.

Przygotowanie każdej kodyfikacji stanowi bardzo poważne wyzwanie, które wymaga dochowania odpowiednich warunków do prowadzenia dyskursu, wymiany stanowisk między praktyką a teorią i właściwego poziomu legislacji. Doświadczenia polskie, zarówno te sięgające okresu międzywojennego, jak i te, które przypadają na okres powojenny i czasy po przełomie politycznym w 1989 r., wskazują na to, że model wykorzystania ciała eksperckiego, w którym współdziałają teoretycy i praktycy, przynajmniej w sferze tradycyjnego prawa prywatnego i prawa karnego oraz postępowań sądowych w sprawach cywilnych i karnych, stanowi dobry modus operandi jako punkt wyjścia w pracach nad kodyfikacją, poprzedzający późniejsze konsultacje i sam proces legislacyjny. Niestety wskazany model został współcześnie w naszym kraju zarzucony, czego symbolicznym przejawem była wspomniana już likwidacja Komisji Kodyfikacyjnej Prawa Cywilnego działającej przy Ministrze Sprawiedliwości. Nie zastąpiono jej innym jawnie działającym ciałem, lecz zdecydowano się na tworzenie projektów odnośnych regulacji prawnych, w tym w dziedzinie prawa postępowania cywilnego, $\mathrm{w}$ ministerialnych gabinetach, przede wszystkim w gronie sędziów niższego szczebla delegowanych do pracy w Ministerstwie Sprawiedliwości, w znacznej mierze w oderwaniu od albo nawet bez znajomości dorobku nauki. Możliwe późniejsze konsultacje, mimo ewentualnego prezentowania w ich ramach stanowisk różnych instytucji oraz zainteresowanych organizacji, nie mają w rezultacie odpowiednio przygotowanego podłoża w postaci dobrego projektu regulacji. Następujące po tym z kolei prace legislacyjne na etapie parlamentarnym obarczone są skutkami istniejących podziałów politycznych i całkowitym brakiem zdolności do osiągania konsensusu. Wszystko to nie może być dobrym prognostykiem co do możliwości przygotowania i wprowadzenia w życie tak wielkiego dzieła normatywnego, jakim byłby nowy Kodeks postępowania cywilnego, w kształcie, który stanowiłby postęp w stosunku do obowiązującej ustawy procesowej.

Dobrym przykładem tego, że takie ryzyko jest niezwykle poważne, jest wprowadzona w ubiegłym 
roku ustawa nowelizująca Kodeks postępowania cywilnego $^{73}$. Przygotowano ją w przedstawionych powyżej, aktualnie panujących uwarunkowaniach, w celu usprawnienia oraz przyspieszenia rozpatrywania spraw cywilnych przez sądy. Całościowa ocena tej nowelizacji jest niewątpliwie zagadnieniem złożonym, gdyż ma ona - w różnych kwestiach szczegóło- egzemplifikuje ona doskonale problem tworzenia prawa postępowania cywilnego w obecnej sytuacji i wpływ sposobu tego tworzenia na jakość osiąganego rezultatu. Jeśli miałby być przygotowywany nowy Kodeks postępowania cywilnego, to z pewnością nie mógłby to być akt prawny podobnej jakości legislacyjnej.

\section{Wzgląd na kondycję Kodeksu postępowania cywilnego} przemawia za podjęciem trudu opracowania nowej kodyfikacji. To, co stawia przed pytaniem o możliwość podjęcia tego trudu, wiąże się z kryzysem kultury tworzenia prawa $w$ ostatnich latach, z następstwami tzw. reformy wymiaru sprawiedliwości oraz niebezpieczeństwami wynikającymi

\section{$z$ instrumentalizacji prawa procesowego cywilnego.}

wych - pewne zalety, jak i poważne wady ${ }^{74}$. Biorąc pod uwagę jednak jej ogólny poziom jako aktu prawnego, nie można jej traktować jako wzorcowego przykładu reformowania jakiejkolwiek dziedziny prawa. Obarczona z jednej strony dużymi niespójnościami i defektami językowymi, a z drugiej strony pozbawiona głębszej refleksji koncepcyjnej ${ }^{75}$ i teoretycznej,

73 Chodzi ustawę z dnia 4 lipca 2019 r., por. przypis 23.

74 M. Gutowski, P. Kardas, O nowym modelu polskiej procedury cywilnej - uwagi wprowadzajace do "Palestry" 11-12/2019 poświęconej nowelizacji kodeksu postępowania cywilnego, „Palestra” 2019, nr 11-12, s. 10 i n.; P. Rylski, O nowelizacji..., s. 16. Co do skutków przyjęcia ustawy z dnia 4 lipca 2019 r. dla kwestii spójności Kodeksu postępowania cywilnego w kontekście oceny potrzeby zastąpienia go nową kodyfikacją por. uwagi powyżej w punkcie 3 .

75 Zwraca uwagę fakt, że uzasadnienie ustawy z dnia 4 lipca 2019 r. nie jest poprzedzone tradycyjnym wskazaniem ogólnych celów wprowadzanych zmian i określeniem ich zakres przedmiotowego, lecz obejmuje przedstawienie wyodrębnio-
Powszechnie podkreśla się związki zachodzące pomiędzy zagadnieniami ustrojowymi, strukturalnymi i organizacyjnymi sądownictwa, problematyką statusu sędziego i warunkami wykonywania przez niego jego funkcji a kształtem przepisów regulujących postępowania przed sądami ${ }^{76}$. $\mathrm{Z}$ jednej strony uregulowania dotyczące organizacji i struktury sądów oraz innych organów związanych z ochroną prawną, sytuacji ustrojowej i zawodowej sędziów, dostępu do kariery sędziowskiej wraz z odpowiednio ukształtowanymi przepisami procesowymi wpływają łącznie na sprawność i efektywność sądownictwa i udzielanej przez

nych zagadnień lub grup zagadnień objętych zmianami. Por. uzasadnienie projektu ustawy o zmianie ustawy - Kodeks postępowania cywilnego oraz niektórych innych ustaw, VIII kadencja Sejmu RP, druk nr 3137.

76 Por. T. Ereciński, O uwarunkowaniach..., s. 12; T. Ereciński, Dalsze zmiany..., s. 3-5; K. Markiewicz, Zagadnienia..., s. $273-275$. 
sądy ochrony prawnej ${ }^{77}$. Z drugiej strony pomiędzy obu tymi kategoriami regulacji zachodzą wzajemne oddziaływanie i współzależność, które powodują, że powinny one być ze sobą odpowiednio zharmonizowane. W rezultacie treść regulacji ustrojowych, strukturalnych i organizacyjnych dotyczących sądów i sędziów wpływa na kształt regulacji obejmujących postępowania sądowe lub wręcz go implikuje - i na odwrót ${ }^{78}$. Sprawia to, że zmianom w obszarze instytucjonalnym wymiaru sprawiedliwości towarzyszą często równolegle lub w nieodległej sekwencji czasowej zmiany prawa sądowego, zarówno $\mathrm{w}$ dziedzinie postępowania cywilnego, jak i postępowania karnego. Co więcej, zmiany w jednej sferze - ze względu na wspomniane powiązania - zmierzać mogą do petryfikacji zmian w drugiej sferze i na odwrót ${ }^{79}$.

W naszym kraju od kilku lat podejmowane są działania legislacyjne zmierzające do zmian w zakresie wymiaru sprawiedliwości w jego wymiarze ustrojowym i organizacyjnym, obejmujące Sąd Najwyższy, sądy powszechne, Naczelny Sąd Administracyjny i Krajową Radę Sądownictwa, a także sytuację ustrojową i zawodową sędziów ${ }^{80}$. Dokonuje się ich pod

77 T. Ereciński, K. Weitz, Efektywność..., s. 3 i n.

78 K. Markiewicz, Zagadnienia..., s. 273. Na przykładzie instytucji właściwości sądu w procesie cywilnym K. Markiewicz, Właściwość sądu w procesie cywilnym wobec przemian politycznych, społecznych i gospodarczych, w: Ewolucja polskiego postępowania cywilnego wobec przemian politycznych, społecznych i gospodarczych. Materiały konferencyjne Ogólnopolskiego Zjazdu Katedr Postępowania Cywilnego Szczecin-Niechorze 28-30.9.2007 r., Warszawa 2009, s. 223 i n., w szczególności - w zakresie konkluzji - s. 243-244.

79 Przykładami tego zjawiska są zmiany ustroju i organizacji wymiaru sprawiedliwości i kształtowanie się prawa postępowania cywilnego w II Rzeczypospolitej, przeprowadzone w tych dziedzinach zmiany w okresie po II wojnie światowej w PRL oraz ich przebudowa po przełomie społeczno-politycznym w 1989 r. Por. w związku z tym ma przykładzie okresu PRL w pierwszych latach powojennych A. Machnikowska, 50-lecie..., s. 554-556.

80 Najnowszym akordem tych zmian jest ustawa $z$ dnia 20.12.2019 r. o zmianie ustawy - Prawo o ustroju sądów powszechnych, ustawy o Sądzie Najwyższym oraz niektórych innych ustaw, Dz.U. 2020, poz. 190, zwana przez jednych „dyscyplinującą", a przez innych „kagańcową”. hasłem zwiększenia efektywności i sprawności sądów ${ }^{81}$. W rzeczywistości sprowadzają się one do podważenia pozycji ustrojowej władzy sądowniczej w stosunku do władzy wykonawczej i ustawodawczej oraz do zmian kadrowych w obszarze sądownictwa. Ich rezultatem jest daleko posunięta i niezwykle groźna dla obywateli dekompozycja władzy sądowniczej, powodująca, że w ujęciu systemowym w znacznej mierze pod znakiem zapytania staje jej zdolność do udzielania ochrony prawnej zgodnie ze standardami konstytucyjnymi, międzynarodowymi i unijnymi ${ }^{82}$. Towarzyszy temu niepewność co do przyszłego możliwego kształtu ewentualnych dalszych zmian w obszarze ustrojowym i instytucjonalnym sądownictwa, których spodziewać się można w nadchodzącym okresie czasu. Taki stan rzeczy z dwóch zasadniczych powodów stanowi jednoznaczne przeciwwskazanie dla podejmowania prac nad nową kodyfikacją prawa postępowania cywilnego ${ }^{83}$. Po pierwsze, obecny kształt ustrojowy i organizacyjny sądownictwa cechuje labilność, wynikająca z tego, że nie wiadomo, czym zakończy się okres dokonywanych zmian i w jakiej sytuacji znajdować się będzie władza sądownicza, sądownictwo i sędziowie po tym okresie. Po drugie, oceniając krytycznie dotychczasowe rezultaty tzw. reformy wymiaru sprawiedliwości, trzeba wprost wyrazić obawę, że przygotowanie oraz wprowadzenie w życie nowej ustawy procesowej mogłoby służyć petryfikacji tych rezultatów, co byłoby - z punktu widzenia obywateli i państwa - bardzo niepożądane.

Każde prawo, a prawo publiczne, którym jest prawo postępowania cywilnego, nawet bardziej niż prawo prywatne, jest podatne na wpływ czynników pozaprawnych, w tym takich, które odzwierciedlają dominujące

81 Do pewnego etapu proces tych zmian w kontekście hasła o sprawności wymiaru sprawiedliwości przedstawia A. Machnikowska, O niezawisłości sędziów i niezależności sądów $w$ trudnych czasach. Wymiar sprawiedliwości w pułapce sprawności, Warszawa 2018, passim.

82 Por. w tym kontekście uchwałę połączonych izb: Cywilnej, Karnej oraz Pracy i Ubezpieczeń Społecznych Sądu Najwyższego z dnia 23.01.2020 r., BSA I-4110-1/20, dostępną na stronie: www.sn.pl.

83 Na obecną sytuację wymiaru sprawiedliwości i władzy sądowniczej jako kontekst wprowadzenia zmian na mocy ustawy z dnia 4 lipca 2019 r. zwracają trafnie uwagę M. Gutowski, P. Kardas, O nowym..., s. 7-8. 
$\mathrm{w}$ danym czasie stosunki społeczne i gospodarcze oraz idee i wartości ${ }^{84}$. Stworzony w okresie międzywojennym Kodeks postępowania cywilnego z 1930 r. stanowił instrument dochodzenia praw indywidualnych podmiotów prawa prywatnego, oparty na klasycznych zasadach mających głębokie zakotwiczenie w ideach liberalizmu sięgających korzeniami XIX w. ${ }^{85}$ Rodzący się po zamachu majowym autorytaryzm ówczesnej władzy, który odcisnął poważne piętno na przyjętych nieco wcześniej regulacjach dotyczących ustroju sądownictwa ${ }^{86}$, nie wywarł takiego wpływu na kształt ustawy procesowej. Odmiennie sytuacja przedstawiała się w okresie PRLu, kiedy niedemokratyczna władza poddała zmianom nie tylko organizację wymiaru sprawiedliwości, lecz idei „budowy socjalizmu” podporządkowała także przemiany prawa procesowego cywilnego, zwieńczone uchwaleniem Kodeksu postępowania cywilnego z 1964 r. Prawo postępowania cywilnego poddane zostało tzw. publicyzacji, wobec czego interesy prywatne stron i uczestników postępowania podporządkowane zostały interesom państwa i społeczeństwa ${ }^{87}$. Był to okres daleko idącej instrumentalizacji prawa procesowego cywilnego, który zaczęto stopniowo odwracać dopiero po przemianach społeczno-politycznych w $1989 \mathrm{r}^{88}$

Ostatnie lata nie stanowią dobrego czasu dla idei liberalizmu oraz klasycznych zasad postępowania cywilnego. Dominuje filozofia etatyzmu i paternalizmu państwa wobec jednostki kosztem zwiększenia jego ingerencji w jej wolność i autonomię. Podejście to pozostaje bliższe czasom sprzed 1989 r. niż ideom demokratycznego państwa prawnego funkcjonującego w ramach liberalnej demokracji. Rodzi ono poważne ryzyko powrotu do instrumentalizacji prawa procesowego cywilnego. Jest tak tym bardziej, że jesteśmy również świadkami rozwoju populizmu prawniczego, świadomie czerpiącego z niedostatecznego poziomu

84 J. Gudowski, O kilku naczelnych..., s. 1015.

85 Tamże, s. 1016; K. Weitz, Die Entwicklung..., s. 91.

86 J. Gudowski, Historia prawa o ustroju sądów powszechnych z 1928 r., "Przegląd Sądowy” 2003, nr 1, s. 19 i n.

87 Por. m.in. J. Jodłowski, Nowe drogi polskiego procesu cywilnego. Założenia ideologiczne reformy postępowania cywilnego (w:) Z zagadnień polskiego procesu cywilnego, Warszawa 1961, s. 31-32.

88 Zob. J. Gudowski, O kilku naczelnych..., s. 1024. kultury prawnej społeczeństwa i serwującego - w imię rzekomej ochrony obywateli przed wyimaginowanym bezprawiem ze strony sądów - rozwiązania podważające pewność ochrony sądowej oraz sens sądowego sprawowania wymiaru sprawiedliwości.

Sztandarowym przykładem tych procesów jest wprowadzenie do polskiego systemu prawnego skargi nadzwyczajnej ${ }^{89}$, która wprost godzi w prawo obywateli do sądu, w tym do ostatecznego rozstrzygnięcia sprawy, i zarazem stanowi potencjalnie narzędzie - inicjowanej politycznie - weryfikacji prawomocnych orzeczeń sądów powszechnych i wojskowych, w tym wydawanych w postępowaniu cywilnym ${ }^{90}$. Odnotować należy również niczym nieuzasadniony proces różnicowania obywateli w sposobie realizacji ich prawa do sądu. Świadczy o tym przywrócenie dawnego postępowania odrębnego w sprawach gospodarczych ${ }^{91}$, opartego na ideach właściwych dla postsowieckiego systemu prawnego i jednocześnie zaostrzającego rygoryzm procesowy w stosunku do osób zajmujących się działalnością gospodarczą $^{92}$. Tylko te dwa przykłady wskazują na to, że obecne uwarunkowania aksjologiczne rodzą ryzyko, iż idea nowej kodyfikacji prawa procesowego cywilnego mogłaby zostać wykorzystana nie do jego ulepszenia i unowocześnienia stosowanie do jego współczesnych wyzwań, lecz posłużyć jako pretekst do przygotowania aktu prawnego, w którym prawo to nie byłoby zorientowane na ochronę interesów podmiotów prawa prywatnego, lecz - znów - stałoby się instrumentem ich podporządkowania państwu i zbiorowości społecznej.

W konkluzji trzeba stwierdzić, że konieczność przygotowania nowej kodyfikacji prawa procesowego cywilnego pozostaje aktualna. Podtrzymując to stanowisko,

89 Przepisy art. 89-95 ustawy z dnia 8.12.2017 r. o Sądzie Najwyższym, tj. Dz.U. 2019, poz. 825 ze zm.

90 T. Ereciński, K. Weitz, Skarga nadzwyczajna $w$ sprawach cywilnych, „Przegląd Sądowy” 2019, nr 2, s. 10-11.

91 Na mocy ustawy z dnia 4 lipca 2019 r.

92 Por. K. Weitz, Czy potrzebne jest postępowanie w sprawach gospodarczych, „Przegląd Sądowy” 2008, nr 7-8, s. 23. Zob. jednak także P. Feliga, Sprawiedliwie załatwienie sprawy gospodarczej jako cel odrębności postępowaniach w sprawach gospodarczych (w:) P. Rylski (red.), Ustawa z 4.7.2019 r. reforma czy kolejna nowelizacja KPC?, Warszawa 2020 , s. 153 i nast. 
należy jednak mieć świadomość istnienia poważnych przeszkód na drodze do opracowania nowego Kodeksu postępowania cywilnego w najbliższej przyszłości.

\section{Bibliografia}

Bieluk J., Marciniak A. (red.), Postępowanie i prawo cywilne $w$ dobie informatyzacji, Sopot [Currenda] 2016.

Błaszczak Ł., Wadliwość czynności procesowych stron i uczestników. Obecny model i propozycja zmian w przyszłym Kodeksie postępowania cywilnego (w:) K. Markiewicz, A. Torbus (red.), Postępowanie rozpoznawcze w przyszłym Kodeksie postępowania cywilnego, Warszawa [C.H. Beck] 2014.

Błaszczak Ł. (red.), Konstytucjonalizacja postępowania cywilnego, Wrocław [Presscom] 2015.

Broniewicz W., Nowelizacja prawa postępowania cywilnego $z$ dnia 1 marca 1996 r., „Kwartalnik Prawa Prywatnego” 1997, z. 2, s. 199-226.

Broniewicz W., Czy potrzebny jest nowy kodeks postępowania cywilnego?, „Państwo i Prawo” 2004, nr 4, s. 11-17.

Czterdziestolecie Kodeksu postępowania cywilnego. Zjazd Katedr Postępowania Cywilnego w Zakopanem (7.-9.10.2005 r.), Kraków [Zakamycze] 2006.

Calmon P., The Future of the Traditional Civil Procedure (w:) M. Kengyel (ed.), Electronic Justice - Present and Future. Colloqium of the International Association of Procedural Law Pécs, September 23-25, 2010, Pécs 2010.

Dolecki H., Flaga-Gieruszyńska K. (red.), Ewolucja polskiego postępowania cywilnego wobec przemian politycznych, społecznych i gospodarczych. Materiały konferencyjne Ogólnopolskiego Zjazdu Katedr Postępowania Cywilnego Szczecin-Niechorze 28-30.9.2007 r., Warszawa [C.H. Beck] 2009.

Dziurda M., Zdolność sądowa i jej znaczenie (w:) K. Markiewicz, A. Torbus (red.), Podmioty w postępowaniu cywilnym, Warszawa [C.H. Beck] 2018.

Ereciński T., O nowelizacji kodeksu postępowania cywilnego w ogólności, „Przegląd Sądowy” 1996, nr 10, s. 3-17.

Ereciński T., Wprowadzenie do ustawy z dnia 24 maja 2000 r. (w:) Kodeks postępowania cywilnego po nowelizacjach $z 2001 \mathrm{r}$, Warszawa [LexisNexis] 2002.

Ereciński T., O potrzebie nowego kodeksu postępowania cywilnego, „Państwo i Prawo” 2004, nr 4, s. 3-10.

Ereciński T., Weitz K., Efektywność ochrony prawnej udzielanej przez sądy w Polsce, „Przegląd Sądowy” 2005, nr 10, s. 3-36.

Ereciński T., O uwarunkowaniach, potrzebie oraz zakresie nowego kodeksu postępowania cywilnego, „Polski Proces Cywilny” 2010, nr 1, s. 9-19
Ereciński T., Weitz K. (red.), Orzecznictwo Trybunału Konstytucyjnego a Kodeks postępowania cywilnego. Materiały Ogólnopolskiego Zjazdu Katedri Zakładów Postępowania Cywilnego, Serock k. Warszawy, 24-26 września 2009 r., Warszawa [LexisNexis] 2010.

Ereciński T., Dalsze zmiany czy nowy Kodeks postępowania cywilnego? (w:) K. Markiewicz (red.), Reforma postępowania cywilnego w świetle projektów Komisji Kodyfikacyjnej, Warszawa [C.H. Beck] 2011.

Ereciński T., Wprowadzenie. O stanie prac nad projektem nowego Kodeksu postępowania cywilnego (w:) K. Markiewicz, A. Torbus (red.), Postępowanie rozpoznawcze w przyszłym Kodeksie postępowania cywilnego, Warszawa [C.H. Beck] 2014.

Ereciński T. (red.), Kodeks postępowania cywilnego. Komentarz, t. 1: Postępowanie rozpoznawcze, Warszawa [Wolters Kluwer] 2016.

Ereciński T., Weitz K., Skarga nadzwyczajna w sprawach cywilnych, „Przegląd Sądowy” 2019, nr 2, s. 7-19.

Feijó M.A., Kochem R.L., What to Expect from the New Brazilian Civil Procedure Code of 2015, „ZZP International” 2015, t. 20 , s. 363-380.

Feliga P., Sprawiedliwie załatwienie sprawy gospodarczej jako cel odrębności postępowaniach w sprawach gospodarczych (w:) P. Rylski (red.), Ustawa z 4.7.2019 r. - reforma czy kolejna nowelizacja KPC?, Warszawa [C.H. Beck] 2020.

Fischer N., Electronification of Civil Litigation and Civil JusticeThe Future of the Traditional Civil Procedure facing the Electronification (w:) M. Kengyel (ed.), Electronic Justice - Present and Future. Colloqium of the International Association of Procedural Law Pécs, September 23-25, 2010, Pécs 2010.

Flaga-Gieruszyńska K., Gołaczyński J., Szostek D., Informatyzacja postępowania cywilnego. Teoria i praktyka, Warszawa [C.H. Beck] 2016.

Flaga-Gieruszyńska K., Informatyzacja w świetle zasad postępowania cywilnego - wybrane zagadnienia (w:) E. Marszałkowska-Krześ, I. Gil, Ł. Błaszczak (red.), Kodeks postępowania cywilnego z perspektywy pięćdziesięciolecia jego obowiązywania. Doświadczenia i perspektywy, Sopot [Currenda] 2016.

Gajda-Roszczynialska K., Między prokuratorem a organizacjami pozarządowymi - udział podmiotów innych niż materialnie uprawnione (uwagi de lege lata $i$ de lege ferenda) (w:) K. Markiewicz, A. Torbus (red.), Podmioty w postępowaniu cywilnym, Warszawa [C.H. Beck] 2018.

Gołąb A., Wybrane aspekty zasady jawności w świetle nowelizacji Kodeksu postępowania cywilnego z 4.7.2019 r. (w:) P. Rylski (red.), Ustawa z 4.7.2019 r. - reforma czy kolejna nowelizacja KPC?, Warszawa [C.H. Beck] 2020. 
Gołaczyński J., Model informatyzacji postępowania cywilnego w nowym Kodeksie postępowania cywilnego (w:) K. Markiewicz, A. Torbus (red.), Postępowanie rozpoznawcze w przyszłym Kodeksie postępowania cywilnego, Warszawa [C.H. Beck] 2014.

Gołaczyński J., Szostek D., Informatyzacja postępowania cywilnego. Komentarz, Warszawa [C.H. Beck] 2016.

Góra-Błaszczykowska A. (red.), Nowelizacja Kodeksu postępowania cywilnego, Sopot [Currenda] 2015.

Górnicki L., Prawo cywilne w pracach Komisji Kodyfikacyjnej Rzeczypospolitej Polskiej w latach 1919-1939, Wrocław [Kolonia Limited] 2000.

Grzegorczyk P., Ustawa o dochodzeniu roszczeń w postępowaniu grupowym. Ogólna charakterystyka, Warszawa [LexisNexis] 2011.

Grzegorczyk P., O konstytucjonalizacji prawa procesowego cywilnego, „Kwartalnik Prawa Prywatnego” 2012, z. 2, s. 293-333.

Grzegorczyk P., Weitz K., Sprawozdanie z I Międzynarodowej Konferencji Międzynarodowego Stowarzyszenia Prawa Procesowego i Iberoamerykańskiego Instytutu Prawa Procesowego Procesos Colectivos/Class Actions, Buenos Aires 6-9 czerwca 2012, „Polski Proces Cywilny” 2013, nr 1, s. 140-143.

Grzegorczyk P., Dopuszczalność $i$ kształt apelacji w postępowaniu cywilnym - perspektywy przyszłej regulacji z uwzględnieniem standardów konstytucyjnych i międzynarodowych (w:) K. Markiewicz, A. Torbus (red.), Postępowanie rozpoznawcze w przyszłym Kodeksie postępowania cywilnego, Warszawa [C.H. Beck] 2014. Grzegorczyk P., Postępowanie grupowe po reformie (w:) Honeste procedere. Ksiegga jubileuszowa dedykowana Profesorowi Kazimierzowi Lubińskiemu, Warszawa [Wolters Kluwer] 2017.

Gudowski J., Historia prawa o ustroju sądów powszechnych z 1928 r., „Przegląd Sądowy” 2003, nr 1, s. 13-24.

Gudowski J., O kilku naczelnych zasadach procesu cywilnego wczoraj, dziś, jutro (w:) Prawo prywatne czasu przemian. Ksiega pamiątkowa dedykowana Profesorowi Stanisławowi Soltysińskiemu, Poznań [Wydawnictwo Naukowe UAM] 2005.

Gutowski M., Kardas P., O nowym modelu polskiej procedury cywilnej - uwagi wprowadzające do „Palestry” 11-12/2019 poświęconej nowelizacji kodeksu postępowania cywilnego, „Palestra” 2019, nr 11-12, s. 7-14.

Jakubecki A., Zdolność sq̨dowa wedtug kodeksu postępowania i przepisów odrębnych (de lege lata $i$ de lege ferenda) (w:) K. Markiewicz, A. Torbus (red.), Postępowanie rozpoznawcze w przyszłym Kodeksie postępowania cywilnego, Warszawa [C.H. Beck] 2014.

Jakubecki A., Zdolność procesowa w Kodeksie postępowania cywilnego (de lege lata $i$ de lege ferenda) - wybrane zagadnienia (w:)
K. Markiewicz, A. Torbus (red.), Podmioty w postępowaniu cywilnym, Warszawa [C.H. Beck] 2018.

Jakubecki A., Czy potrzebne jest nam postępowanie odrębne w sprawach gospodarczych? (uwagi na tle projektu ustawy o zmianie ustawy - Kodeks postępowania cywilnego z 13 września 2018 r.), „Radca Prawny ZN” 2018, nr 4, s. 53-70.

Jankowski J., Nowelizacje KPC wprowadzone w 2005 r., Warszawa [C.H. Beck] 2005.

Jodłowski J., Nowe drogi polskiego procesu cywilnego. Założenia ideologiczne reformy postępowania cywilnego (w:) J. Jodłowski, Zzagadnień polskiego procesu cywilnego, Warszawa [PWN] 1961. Litauer J.J., Polska Procedura Cywilna. Projekty uchwalone przez Komisję Kodyfikacyjną. Kodeks postępowania cywil nego. Ustawa o wprowadzeniu kodeksu. Ustawa o kosztach sądowych. Uzasadnienie ogólne i tekst projektów, Warszawa [Drukarnia Mazowiecka] 1930.

Kengyel M. (red.), Electronic Justice - Present and Future. Colloquium of the International Association of Procedural Law Pécs, September 23-25, 2010, Pécs 2010.

Kulski R., Ochrona interesów zbiorowych w postępowaniu cywilnym, Warszawa [C.H. Beck] 2017.

Lubiński K., Teoretyczne a legislacyjne podstawy przekazywania spraw do procesu i postępowania nieprocesowego w nowym Kodeksie postępowania cywilnego (w:) E. Marszałkowska-Krześ, I. Gill, Ł. Błaszczak (red.), Kodeks postępowania cywilnego z perspektywy pięćdziesięciolecia jego obowiązywania. Doświadczenia i perspektywy, Sopot [Currenda] 2016.

Machnikowska A., 50-lecie Kodeksu postępowania cywilnego $z$ dalekiej i bliskiej perspektywy, „Kwartalnik Prawa Prywatnego" 2015, z. 3, s. 551-587.

Machnikowska A., O niezawisłości sędziów i niezależności sądów w trudnych czasach. Wymiar sprawiedliwości w pułapce sprawności, Warszawa [Wolters Kluwer] 2018.

Manowska M., Zmiany w kodeksie postępowania cywilnego wprowadzone w 2004 r., „Przegląd Sądowy” 2005, nr 5, s. 3-46.

Markiewicz K., Właściwość sądu w procesie cywilnym wobec przemian politycznych, społecznych i gospodarczych (w:) H. Dolecki, K. Flaga-Gieruszyńska (red.), Ewolucja polskiego postępowania cywilnego wobec przemian politycznych, społecznych i gospodarczych. Materiały konferencyjne Ogólnopolskiego Zjazdu Katedr Postępowania Cywilnego Szczecin-Niechorze 28-30.9.2007 r., Warszawa [C.H. Beck] 2009.

Markiewicz K. (red.), Reforma postępowania cywilnego w świetle projektów Komisji Kodyfikacyjnej, Warszawa [C.H. Beck] 2011.

Markiewicz K., Walasik M., Założenia wstępne dotyczące przepisów o postępowaniu nieprocesowym w nowym Kodeksie 
postępowania cywilnego przyjęte przez zespół problemowy Komisji Kodyfikacyjnej Prawa Cywilnego do spraw postępowania cywilnego, „Przegląd Sądowy” 2012, nr 9, s. 101-111.

Markiewicz K., Torbus A. (red.), Postępowanie rozpoznawcze w przyszłym Kodeksie postępowania cywilnego, Warszawa [C.H. Beck] 2014.

Markiewicz K., Torbus A., Wolwiak I., Założenia doręczeń w postępowaniu cywilnym, „Polski Proces Cywilny” 2014, nr 2, s. 301-313.

Markiewicz K., Informatyzacja postępowania cywilnego - de lege lata $i$ de lege ferenda (w:) K. Markiewicz, A. Torbus (red.), Postępowanie rozpoznawcze w przyszłym Kodeksie postępowania cywilnego, Warszawa [C.H. Beck] 2014.

Markiewicz K., Właściwość sądu, skład sądu i wyłączenie sędziego w pracach Komisji Kodyfikacyjnej Prawa Cywilnego, „Polski Proces Cywilny" 2015, nr 2, s. 278-301.

Markiewicz K., Zagadnienia legislacyjne w pracach nad przyszłym kodeksem postępowania cywilnego (w:) W. Brzozowski, A. Krzywoń (red.), Leges ab omnibus intellegi debent. Ksiegg XV-lecia Rządowego Centrum Legislacyjnego, Warszawa [Wydawnictwo Sejmowe] 2015.

Markiewicz K., Właściwość i skład sądu (w:) K. Markiewicz, A. Torbus (red.), Podmioty w postępowaniu cywilnym, Warszawa [C.H. Beck] 2018.

Marszałkowska-Krześ E., Gil I., Błaszczak Ł. (red.), Kodeks postępowania cywilnego z perspektywy pięćdziesięciolecia jego obowiązywania. Doświadczenia i perspektywy, Sopot [Currenda] 2016.

Oteiza E. (red.), Procesos colectivos/Class actions, Buenos Aires [Cathedra Jurídica] 2012.

Pogonowski P., Wplyw wejścia w życie Konstytucji RP z 1997 r. na sądowe postępowanie cywilne (w:) Czterdziestolecie Kodeksu postępowania cywilnego. Zjazd Katedr Postępowania Cywilnego w Zakopanem (7.-9.10.2005 r.), Kraków [Zakamycze] 2006.

Rylski P., Projekt nowej jednolitej szwajcarskiej procedury cywilnej w'świetle dyskusji nad założeniami nowego polskiego kodeksu postępowania cywilnego, „Przegląd Sądowy” 2007, nr 11-12, s. $164-189$.

Rylski P., O nowelizacji Kodeksu postępowania cywilnego ustawa z 4.07.2019 r. w ogólności, „Palestra” 2019, nr 11-12, s. 15-35.

Rylski P., Zmiany w przepisach o postępowaniu apelacyjnym w świetle modelu apelacji cywilnej, „Polski Proces Cywilny” 2020, nr 1, s. 119-142.

Rzewuska M., Dochodzenie roszczeń w postępowaniu grupowym stan obecny i perspektywy zmian (w:) E. Marszałkowska-Krześ,
I. Gil, Ł. Błaszczak (red.), Kodeks postępowania cywilnego z perspektywy pięćdziesięciolecia jego obowiązywania. Doświadczenia i perspektywy, Sopot [Currenda] 2016.

Safjan M., Bosek L. (red.), Konstytucja RP. Komentarz, t. 1-2, Warszawa [C.H. Beck] 2016.

Walasik M., Zakres regulacji nowego Kodeksu postępowania cywilnego (w:) K. Markiewicz, A. Torbus (red.), Postępowanie rozpoznawcze w przyszłym Kodeksie postępowania cywilnego, [C.H. Beck] Warszawa 2014.

Weitz K., Die Entwicklung des polnischen Zivilprozessrechts nach der politischen Wende 1989, „ZZP International” 2006, t. 11, s. 96-115.

Weitz K., Czy nowa kodyfikacja postępowania cywilnego?, „Państwo i Prawo" 2007, nr 3, s. 13-27.

Weitz K., Czy potrzebne jest postępowanie w sprawach gospodarczych, „Przegląd Sądowy” 2008, nr 7-8, s. 22-35.

Weitz K., Reformen des Zivilprozessrechts in der dritten polnischen Republik (w:) Th. Sutter-Somm, V. Harsági (Hrsg.), Die Entwicklung des Zivilprozessrechts in Mitteleuropa um die Jahrtausendwende. Reform und Kodifikation - Tradition und Erneuerung, Zürich-Basel-Genf [Schulthess] 2012.

Weitz K., Skarga o wznowienie postępowania w przyszłym Kodeksie postępowania cywilnego (w:) K. Markiewicz, A. Torbus (red.), Postępowanie rozpoznawcze w przyszłym Kodeksie postępowania cywilnego, Warszawa [C.H. Beck] 2014.

Weitz K., Wpływ prawa Unii Europejskiej na krajowe prawo procesowe cywilne, „Kwartalnik Prawa Prywatnego” 2019, z. 2, s. 297-333.

Zalesińska A., Wpływ informatyzacji na założenia konstrukcyjne procesu cywilnego, Warszawa [C.H. Beck] 2016.

Zedler F., Co dalej z kodeksem postępowania cywilnego (w:) Czterdziestolecie Kodeksu postępowania cywilnego. Zjazd Katedr Postępowania Cywilnego w Zakopanem (7.-9.10.2005 r.), Kraków [Zakamycze] 2006.

Zedler F., Wybrane problemy współczesnego postępowania cywilnego (w:) E. Marszałkowska-Krześ, I. Gil, Ł. Błaszczak (red.), Kodeks postępowania cywilnego z perspektywy pięćdziesięciolecia jego obowiązywania. Doświadczenia i perspektywy, Sopot [Currenda] 2016.

Zembrzuski T. (red.), Kodeks postępowania cywilnego. Koszty sadowe w sprawach cywilnych. Dochodzenie roszczeń w postępowaniu grupowym. Przepisy przejściowe. Komentarz do zmian, Warszawa [Wolters Kluwer] 2019.

Zembrzuski T., Zażalenie po nowelizacji, czyli o standardzie środka zaskarżenia, „Palestra” 2019, nr 11-12, s. 242-262. 